\title{
PENGEMBANGAN AGROFORESTRY SEDERHANA DI SEKITAR RUMAH
}

\author{
Eno Suwarno** ${ }^{1}$, Eni Suhesti ${ }^{2}$, Nahlunnisa ${ }^{3}$ \\ ${ }^{1,2,3}$ Fakultas Kehutanan, Universitas Lancang Kuning \\ Jl. Yos Sudarso Km 8 Rumbai, Pekanbaru, Telp. (0761) 7078907 \\ *E-mail: enosuwarno@unilak.ac.id
}

\begin{abstract}
Based on the results of observations by the Unilak IbM Team on farmer groups assisted by Salimah, Pekanbaru's Rumbai Pesisir Sub-District, there are still many yard and terrace houses that can be used for crop cultivation, either planted directly on the ground or in pots. This condition led to the idea of utilizing these lands to help communities obtain additional income through simple agroforestry based cultivation. The problems faced by partners in developing simple agroforestry around the house are lack of knowledge, availability of facilities, and cultivation techniques. Through counseling, there was a significant increase in understanding between before and after participating in the socialization activities. Field assistance is carried out from the start of the preparation of plant media to maintenance. After about five months since the planting of aloe vera, soursop and binahong plants grew almost $100 \%$ with different growth rates. The difference in growth is due to differences in maintenance intensity, influence of storage location, and place of planting. Plant Moringa percent growth of about 45\%. It is suspected that the moringa seeds that were distributed were still too young where environmental changes and physical disturbances could cause death.
\end{abstract}

Keywords-Agroforestry, Yard, Aloe Vera, Coastal Tassel

\begin{abstract}
Abstrak
Berdasarkan hasil pengamatan Tim IbM Unilak pada kelompok tani ibu-ibu binaan Salimah Kecamatan Rumbai Pesisir Kota Pekanbaru, masih banyak terdapat lahan-lahan pekarangan dan teras rumah warga yang bisa dimanfaatkan untuk budidaya tanaman, baik ditanam langsung di tanah atau di dalam pot. Kondisi ini memunculkan gagasan untuk memanfaatkan lahan-lahan tersebut guna membantu masyarakat memperoleh tambahan penghasilan melalui budidaya agroforestry sederhana berbasis. Permasalahan yang dihadapi oleh mitra dalam pengembangan agroforestry sederhana sekitar rumah adalah kurangnya pengetahuan, ketersediaan saranaprasarana, dan tehnik budidaya. Melalui penyuluhan menunjukan terdapat peningkatan pemahaman yang signifikan antara sebelum dan setelah mengikuti kegiatan sosialisasi. Pendampingan lapangan dilakukan sejak mulai penyiapan media tanaman hingga pemeliharaan. Setelah lebih kurang lima bulan sejak penanaman tanaman lidah buaya, sirsak dan binahong tumbuh hampir 100\% dengan tingkat pertumbuhannya yang berbeda-beda. Perbedaan pertumbuhan dikarenakan perbedaan intensitas pemeliharaan, pengaruh lokasi penyimpanan, dan tempat penanaman. Tanaman kelor persen tumbuhnya sekitar 45\%. Diduga bibit kelor yang dibagikan masih terlalu muda dimana terjadinya perubahan lingkungan dan gangguan fisik dapat menyebabkan terjadinya kematian.
\end{abstract}

Kata Kunci-Agroforestry, Pekarangan, Lidah Buaya, Rumbai Pesisir

\subsection{Analisis Situasi}

\section{PENDAHULUAN}

Berdasarkan hasil pencermatan Tim IbM Unilak pada calon mitra Ibu-Ibu Salimah yang tersebar di Kecamatan Rumbai Kota Pekanbaru, masih banyak terdapat lahan-lahan pekarangan dan teras rumah warga yang bisa dimanfaatkan untuk budidaya tanaman, baik ditanam langsung di tanah atau di dalam pot. Kondisi ini memunculkan gagasan untuk memanfaatkan lahan-lahan tersebut 
guna membantu masyarakat memperoleh tambahan penghasilan melalui budidaya agroforestry mini berbasis lidah buaya.

Menurut Ashari et. al. (2012), pemanfaatan lahan pekarangan secara teknis relatif mudah dilakukan. Sistem pertanian di lahan pekarangan memiliki kelebihan yaitu relatif mudah diawasi karena berlokasi dekat dengan pemilik. Disamping itu, bercocok tanam di pekarangan memiliki sejumlah keunggulan diantaranya pemeliharaannya dapat dilakukan setiap saat, mudah dijangkau, menghemat waktu, ekonomis, efisien dan efektif.

Sebenarnya sebagian kecil anggota masyarakat juga sudah ada yang menanam pohon-pohonan dan lidah buaya. Hanya saja tujunnya sekedar sebagai tanaman hias pelengkap tidak untuk dikomersialkan. Berdasarkan hasil komunikasi pendahuluan yang dilakukan oleh tim IbM Unilak dengan calon mitra peserta pemberdayaan, mereka memiliki minat yang besar untuk menjadi peserta dalam program budidaya pola agroforestry mini berbasis lidah buaya di pekarangan dan teras rumah untuk tujuan komersial, yaitu dalam rangka memperoleh tambahan penghasilan.

\subsection{Permasalahan Mitra}

Secara umum permasalahan yang dihadapi oleh mitra adalah minimnya gagasan untuk melakukan kegiatan-kegiatan kecil yang cukup berpengaruh untuk memperoleh tambahan pendapatan. Hal ini lazimnya disebabkan oleh kurangnya informasi, pengetahuan, modal awal dan jaringan pemasaran. Demikian juga dengan rencana budidaya pola agroforestry mini berbasis lidah buaya. Pada umumnya calon mitra mengalami masalah dalam hal pengetahuan, penyediaan bibit, tehnik budidaya dan pemasaran. Di sisi lain tim IbM Unilak memiliki pengetahuan dan pengalaman untuk ikut membantu menyelesaikan permasalahan-permasalan tersebut dengan dukungan dari institusinya (Universitas Lancang Kuning). Dengan terbantunya penyelesaian permasalahan yang dihadapi oleh mitra, maka diharapkan kesulitan ekonomi yang dihadapi oleh mitra setiap bulannya dapat terbantu dengan adanya tambahan pendapatan dari hasil budidaya pola agroforestry mini berbasis lidah buaya.

\section{SOLUSI YANG DITAWARKAN}

\subsection{Solusi Yang Ditawarkan}

Secara umum solusi yang ditawarkan untuk mengatasi masalah-masalah yang dihadapi oleh mitra adalah pengembangan budidaya pola agroforestry mini berbasis lidah buaya di sekitar rumah, baik ditanamn di tanah langsung atau di dalam pot yang disimpan di teras rumah. Sistem agroforestry adalah suatu bentuk pengelolaan lahan yang memadukan kegiatan pengelolaan pohon kayu-kayuan dengan tanaman pertanian. Model-model agroforestry bervariasi mulai sederhana hingga kompleks, yang memadukan pengelolaan banyak spesies pohon dengan aneka jenis tanaman pertanian, dan bahkan juga dengan ternak atau perikanan, dan pengembangan HHBK unggulan antara lain lebah madu, sutera alam, bambu, rotan, nyamplung dan gaharu (Nair 1993; Reyes 2008)

Berdasarkan pengalaman pendampingan Tim IbM Unilak kepada Kelompok Tani Lidah Buaya Kita di kecamatan Rumbai Pesisir Kota Pekanbaru Provinsi Riau, Prasetyaningsih et. al. (2017) menerangkan bahwa pelepah lidah buaya dipanen 2 (dua) kali dalam sebulan dan dijual dengan harga Rp.5.000 ampai dengan Rp.7.000/kg. Dalam satu rumah, sekali panen rata-rata 60 pelepah atau $60 \mathrm{~kg}$ sehingga dalam sebulan pendapatan dari penjualan pelepah lidah buaya sekitar Rp. 600.000 sampai dengan Rp. 840.000 per bulan.

Mengingat mudahnya persyaratan tumbuh dan banyaknya manfaat lidah buaya, serta memiliki nilai ekonomi yang cukup tinggi, maka pilihan budidaya lidah buaya di lahan pekarangan warga dapat menjadi solusi untuk meningkatkan pendapatan warga masyarakat yang akan menjadi mitra engabdian tim Unilak. Warga masyarakat calon peserta akan dipilih berjumlah sekitar 10 Kepala Keluarga (KK). Secara ringkas pada Tabel 1 ditampilkan permasalahan yang dihadapi oleh mitra, solusi yang ditawarkan, dan target luaran yang ingin dicapai

Tabel 1. Permasalahan, solusi yang ditawarkan, dan target luaran

\begin{tabular}{lll}
\hline \multicolumn{1}{c}{ Permasalahan } & \multicolumn{1}{c}{ Solusi yang ditawarkan } & \multicolumn{1}{c}{ Target luaran } \\
\hline Pengetahuan dan & Pelatihan dan pendampingan & - Menghasilkan produk \\
keterampilan budidaya & tehnik budidaya pola & yang bisa dijual \\
\hline
\end{tabular}




\begin{tabular}{|c|c|c|}
\hline $\begin{array}{l}\text { pola agroforestry mini } \\
\text { berbasis lidah buaya }\end{array}$ & $\begin{array}{l}\text { agroforestry mini berbasis } \\
\text { lidah buaya }\end{array}$ & \\
\hline $\begin{array}{l}\text { Penyediaan bibit, } \\
\text { sarana-prasarana, dan } \\
\text { modal kerja }\end{array}$ & $\begin{array}{l}\text { Pengadaan sarana pendukung } \\
\text { (bibit, pupuk kompos, } \\
\text { peralatan, dan lain-lain) }\end{array}$ & $\begin{array}{l}\text { Tersedianya sarana } \\
\text { pendukung yang } \\
\text { dibutuhkan dalam jumlah } \\
\text { yang cukup }\end{array}$ \\
\hline $\begin{array}{l}\text { Pemanenan dan } \\
\text { penanganan panca } \\
\text { panen }\end{array}$ & $\begin{array}{l}\text { Tehnik pemanenan dan } \\
\text { pengemasan produk }\end{array}$ & $\begin{array}{l}\text { Hasil panen yang } \\
\text { berkualitas dengan } \\
\text { pengemasan yang baik }\end{array}$ \\
\hline Pemasaran produk & $\begin{array}{l}\text { Pelatihan dan pendampingan } \\
\text { akses pasar }\end{array}$ & $\begin{array}{l}\text { Terjualnya produk lidah } \\
\text { buaya }\end{array}$ \\
\hline
\end{tabular}

Selain jenis tanaman lidah buaya, jenis tanaman lain yang diberikan kepada mitra dimana jenis ini mudah dibudidayakan dan memiliki khasiat obat adalah bibit binahong. Saat ini daun binahong sudah beredar di pasaran dalam bentuk teh celup. Adapun jenis tanaman pohon-pohonan tahunan yang mudah ditanam di sekitar rumah adalah jenis pohon kelor dan pohon sirsak. Kedua jenis pohon ini produk-produk herbalnya juga sudah beredar di pasaran. Diyakini bahwa kedua jenis pohon ini juga memiliki banyak khasiat dan manfaat, baik dari buahnya, daunnya, hingga akarnya.
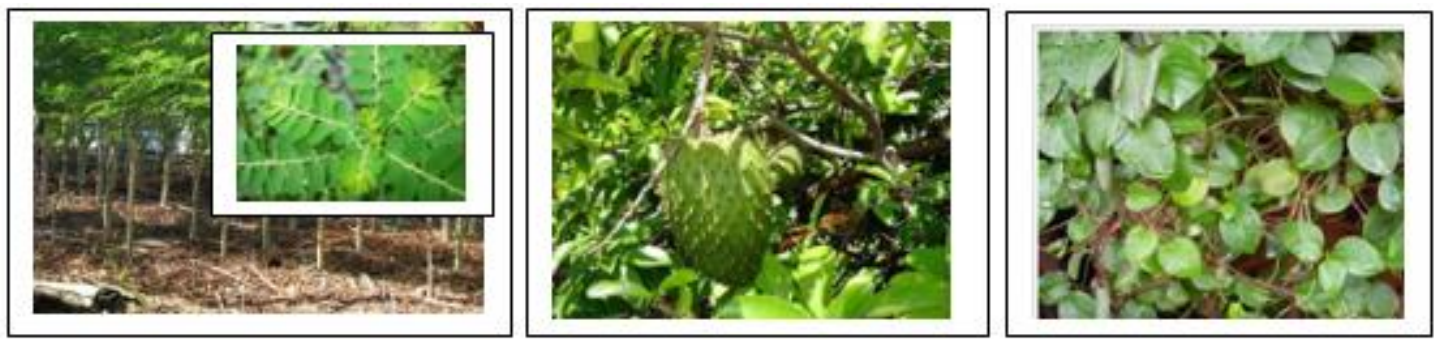

Gambar 2. Contoh Tanaman Pohon Kelor, Sirsak, Dan Binahong Yang Ditanam Penduduk

\section{METODE PELAKSANAAN}

Lingkup kegiatan $\mathrm{IbM}$ yang dilaksanakan secara garis besar terdiri dari empat kelompok kegiatan yang dilakukan secara simultan, yaitu: (1) penyiapan kelompok, (2) penyuluhan agroforestry, (3) Pengadaan sarana-prasarana, dan (4) pendampingan lapangan, dengan rincian sebagai berikut:

\section{Penyiapan kelompok}

a) Pendataan calon anggota

b) Melakukan komunikasi dengan calon anggota dan pihak-pihak terkait

c) Membentuk kelompok

\section{Penyuluhan agroforestry}

Kegiatan penyuluhan diberikan oleh tim IbM terhadap mitra dengan cara dikumpulkan di salah satu tempat anggota kelompok tani. Jenis penyuluhan dan pelatihan yang dilaksanakan adalah penyuluhan budidaya pola agroforestry sederhana berbasis lidah buaya. Materi yang akan disampaikan antara lain: Pengertian agroforestry, pengenalan jenis-jenis tanaman agroforestry, teknik penyiapan media tanam, tehnik penanaman, teknik pemeliharaan, tehnik pemanenan dan penanganan pasca panen.

\section{Pengadaan Sarana-Prasarana}

Jenis sarana-prasarana yang dibutuhkan terdiri dari dua kelompok, yaitu:

a) Pengadaan peralatan dan media tanam: ember bekas, tanah, pupuk kandang, obat-obatan anti hama dan penyakit, dan lain-lain.

b) Pengadaan bibit tanaman: bibit pohon kelor, pohon sirsak, bibit lidah buaya dan bibit binahong. 


\section{Kegiatan Lapangan}

Kegiatan lapangan dilaksanakan dalam bentuk:

a) Pendampingan persiapan tanaman hingga penanaman

b) Pendampingan pemeliharaan dan pengamanan tanaman

\section{HASIL DAN PEMBAHASAN}

Lingkup kegiatan IbM yang dilaksanakan secara garis besar terdiri dari 4 (empat) kelompok kegiatan, yaitu: (1) Penyiapan kelompok, (2) Penyuluhan dan pelatihan, (3) Pengadaan saranaprasarana, dan (4) Pendampingan lapangan.

\section{a. Penyiapan Kelompok}

Penyiapan kelompok mitra yang terdiri dari ibu-ibu yang suka bertani di sekitar rumah, dibantu oleh Ketua Pengurus Salimah Kecamatan Rumbai Pesisir, Ibu Istiahul Azmi, ST. Ternyata Salimah Kecamatan Rumbai Pesisir sudah memiliki binaan yaitu ibu-ibu kelompok tani yang diketuai oleh Ibu Nurbaiti. Anggota kelompok tani ini berjumlah 15 orang. Untuk menggenapkan menjadi 20 orang, maka diundang ibu-ibu lain yang menjadi kenalan dari Ibu Nurbaiti dan ibu-ibu lainnya.

\section{b. Penyuluhan Agroforestry}

Penyuluhan agroforestry dilakukan di rumah ketua kelompok tani yaitu Ibu Nurbaiti. Peserta yang ada hadir 18 orang. Materi yang akan disampaikan adalah pengenalan jenis-jenis tanaman agroforestry, tehnik penanaman, dan teknik pemeliharaan. Penekanan penyuluhan adalah kepada jenis-jenis tanaman agroforestry yang bisa ditanam di sekitar rumah. Jenis-jenis tanaman tersebut adalah: lidah biaya, pohon sirsak, binahong, dan kelor. Selain dijelaskan aspek teknik budidaya, juga dijelaskan manfaatnya bahwa jenis-jenis tersebut semuanya memiliki khasiat obat. Dengan demikian maka dengan menanam jenis-jenis tersebut berarti telah menyiapkan bahan obat-obatan di sekitar rumah, yang dapat dimanfaatkan apabila diperlukan. Terlebih untuk jenis kelor, selain untuk obat juga bisa digunakan sebagai bahan sayuran.

Selain itu, penyuluhan ini juga bertujuan untuk memberi motivasi kepada ibu-ibu peserta agar bisa mengembangkan bibit yang diberikan, khususnya jenis lidah buaya, yang bisa ditanam lebih banyak di polybag, pot atau ember bekas. Apabila sudah mencapai umur 1 tahun, pelepahnya bisa dipanen setiap minggu dan bisa digunaan sendiri atau dijual kepada pihak-pihak yang yang sudah biasa menampungnya dengan harga yang menarik. Dengan demikian maka dari hasil penjualan ini dapat membantu menambah pendapatan keluarga.

Kegiatan sosialisasi ini dilakukan dengan metode ceramah dan diskusi. Untuk mengetahui sejauh mana perubahan pengetahuan dan pemahaman mitra setelah mengikuti acara sosialisasi oleh tim pengabdian, dilakukan pengukuran sebelum (pre-test) dan setelah (post-test) kegiatan dengan pengisian kuesioner. Pertanyaan kuesioner seputar agroforestry (pengertian agroforestry, klasifikasi agroforestry, manfaat ekonomi agroforestry, manfaat lingkungan agroforestry, pengertian multiperpose tree species), manfaat dan khasiat tanaman (tanaman lidah buaya, sirsak, kelor, binahong), penyaiapan media tanam, dan teknik budidaya tanaman yang dibagikan.

Kuesioner direkapitulasi kemudian diolah menggunakan program SPSS. Untuk membandingkan adanya perbedaan yang signifikan atau tidak antara sebelum mengikuti kegiatan sosialisasi dengan setelah mengikuti kegiatan dilakukan uji $t$-student 2 sampel berpasangan. Hasil pengujian tersebut disajikan pada Tabel 32

Tabel 2. Hasil pengujian pengetahuan mitra sebelum dan setelah mengikuti sosialisasi dengan uji t student 2 sampel berpasangan

\begin{tabular}{|c|c|c|c|c|c|c|c|}
\hline \multicolumn{5}{|c|}{ Paired differences } & \multirow{3}{*}{$\mathrm{t}$} & & \multirow{3}{*}{$\begin{array}{l}\text { Sig (2- } \\
\text { tailed) }\end{array}$} \\
\hline \multirow[t]{2}{*}{ Mean } & \multirow[t]{2}{*}{$\begin{array}{c}\text { Std. } \\
\text { deviatio } \\
\mathrm{n}\end{array}$} & \multirow[t]{2}{*}{$\begin{array}{l}\text { Std } \\
\text { error } \\
\text { mean }\end{array}$} & \multirow{2}{*}{\multicolumn{2}{|c|}{$\begin{array}{l}\text { 95\% confidence } \\
\text { interval of the } \\
\text { difference }\end{array}$}} & & $\mathrm{df}$ & \\
\hline & & & & & & & \\
\hline
\end{tabular}




\begin{tabular}{lllllllll}
\hline Sebelum & $-1,674$ & 1,325 & 0,253 & $-2,232$ & $-1,116$ & $-5,406$ & 18 & 0,00 \\
- & & & & & & & & \\
sesudah & & & & & & & & \\
\hline
\end{tabular}

Hasil pengujian pada tabel 2 menunjukkan terdapat perbedaan pemahaman secara signifikan antara sebelum dan setelah mengikuti kegiatan sosialisasi. Hal tersebut ditujukkan oleh angka sig (2-tailed) sebesar 0,00 dengan nilai t sebesar $-5,406$ dan standar deviasi sebesar 1,325. Nilai pemahaman hasil pengukuran melalui quisioner setelah mengikuti sosialisasi jauh lebih tinggi dari pada sebelum mengikuti sosialisasi. Dengan hasil pengujian tersebut dapat dikatakan bahwa mitra pengabdian telah memahami materi yang disampaikan oleh tim pengabdian Unilak

\section{c. Pengadaan Sarana-Prasarana}

Pengadaan sarana-prasarana agroforestry terdiri dari pengadaan tanah hitam, pupuk kandang, abu sekam, dan bibit tanaman. Adapun peralatan dan bahan kerja seperti cangkul, wadah untuk tanaman, dan bahan-bahan lainnya disiapkan oleh ibu-ibu mitra tani.

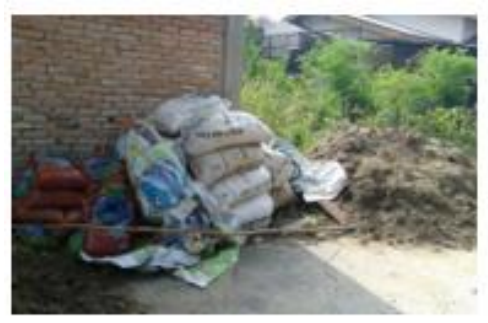

Gambar 3. Pupuk Dan Media Tanam

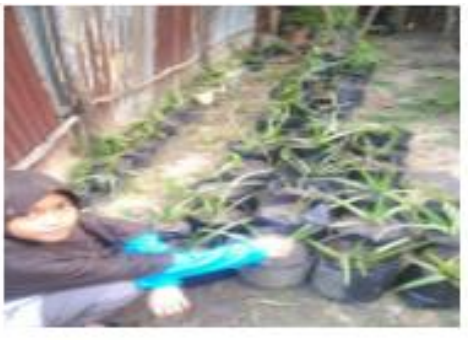

Gambar 4. Bibit Lidah Buaya

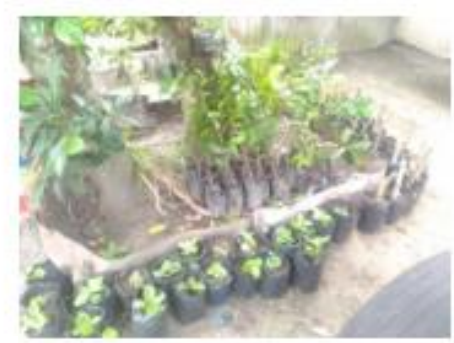

Gambar 5. Bibit Sirsak, Kelor, Dan Binahong

\section{d. Pendampingan Lapangan}

Pendampingan lapangan dilakukan sejak mulai penyiapan media tanaman, Penyiapan media tanam yang terdiri dari campuran dari tanah hitam, pupuk kandang dan abu sekam padi dibuat dengan perbandingan 2:1:1. Ketiga bahan tersebut dicampur merata menggunakan cangkul. Selanjutnya media yang sudah dicampur tersebut dibagi-bagi kepada seluruh anggota dengan dimasukan ke dalam karung, lalu dibawa pulang ke rumah masing-masing.

Di rumah masing-masing media tadi kemudian dimasukkan ke dalam wadah tanam. Ibu-ibu mitra ada yang menggunakan karung bekas beras, ada juga yang menggunakan ember bekas cat, pot platik, pot bekas drum, dan polybag. Selanjutnya bibit tanaman ditanam pada media yang telah disiapkan.

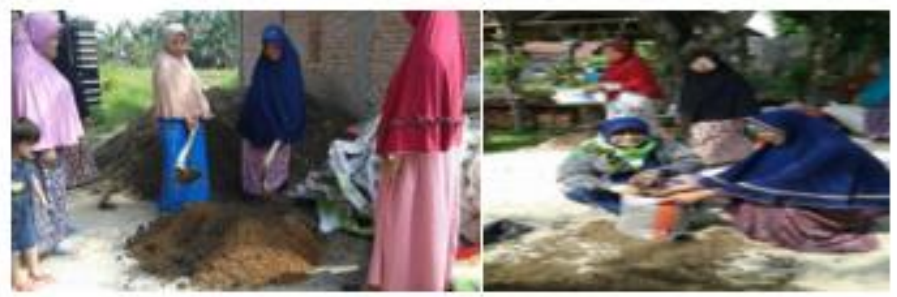

Gambar 6. Kegiatan Penyiapan Media Tanam, Pembagian Bibit, Dan Penanaman Bibit Oleh IbuIbu Mitra

\section{e. Perkembangan Tanaman}

Setelah lebih kurang lima bulan sejak penanaman (Pebruari - Mei 2018), dilakukan pengecekan terhadap tanaman yang dibagikan. Berdasarkan hasil wawancara dan observasi lapangan diperoleh informasi dari ibu-ibu mitra bahwa tanaman lidah buaya, sirsak dan binahong tumbuh hampir $100 \%$. Hanya saja tingkat pertumbuhannya berbeda-beda. Perbedaan pertumbuhan dikarenakan perbedaan intensitas pemeliharaan (penyiangan, penyiraman, pemupukan, dan perlindungan dari gangguan), pengaruh lokasi penyimpanan (di tempat terbuka, teduh, atau sangat teduh), tempat penanaman (ukuran pot, polybag, karung bekas, atau di tanah langsung). 
Tabel 3. Perkembangan tanaman setelah 5 bulan

\begin{tabular}{lcll}
\hline $\begin{array}{l}\text { Jenis Tanaman } \\
\text { Perkembangan }\end{array}$ & $\%$ hidup & Tingkat Pertumbuhan & \multicolumn{1}{c}{ Keterangan } \\
\hline Lidah Buaya & 100 & Normal & $\begin{array}{l}\text { Cepat merambat dan } \\
\text { sudah bisa dibiakan } \\
\text { secara vegetatif }\end{array}$ \\
\hline Binahong & 95 & Bagus & Rata-rata tinggi 50 Cm \\
\hline Sirsak & 100 & Normal & $\begin{array}{l}\text { Banyak mati layu di } \\
\text { awal dengan sebab yang } \\
\text { belum diketahui }\end{array}$ \\
\hline Kelor & 45 & $\begin{array}{l}\text { Yang hidup tumbuh } \\
\text { bagus }\end{array}$ \\
\hline
\end{tabular}

Sedangkan untuk jenis kelor persen tumbuhnya sekitar $45 \%$, artinya lebih banyak yang mati daripada yang hidup. Diduga bibit kelor yang dibagikan masih terlalu muda (baru berusia 2-3 minggu). Pada usia tersebut bibit kelor masih berada pada periode kritis, dimana terjadinya perubahan lingkungan dan gangguan fisik dapat menyebabkan kematian. Oleh karena itu jenis kelor pada usia muda membutuhkan perlakuan khusus dalam hal pencahayaan, suhu dan kelembaban. Pada saat awal pertumbuhan masih membutuhkan naungan dan kelembaban yang tinggi, namun air di dalam media tidak boleh tergenang.

Kondisi tanaman setelah berumur lebih kurang lima bulan sebagaimana pada gambar-bambar di bawah.
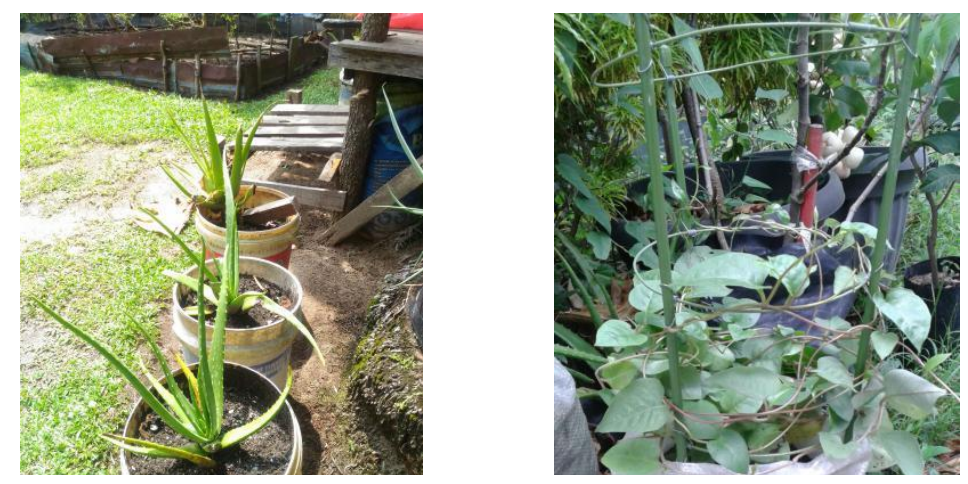

Gambar 7. Tanaman Lidah Buaya Dan Binahong Setelah 5
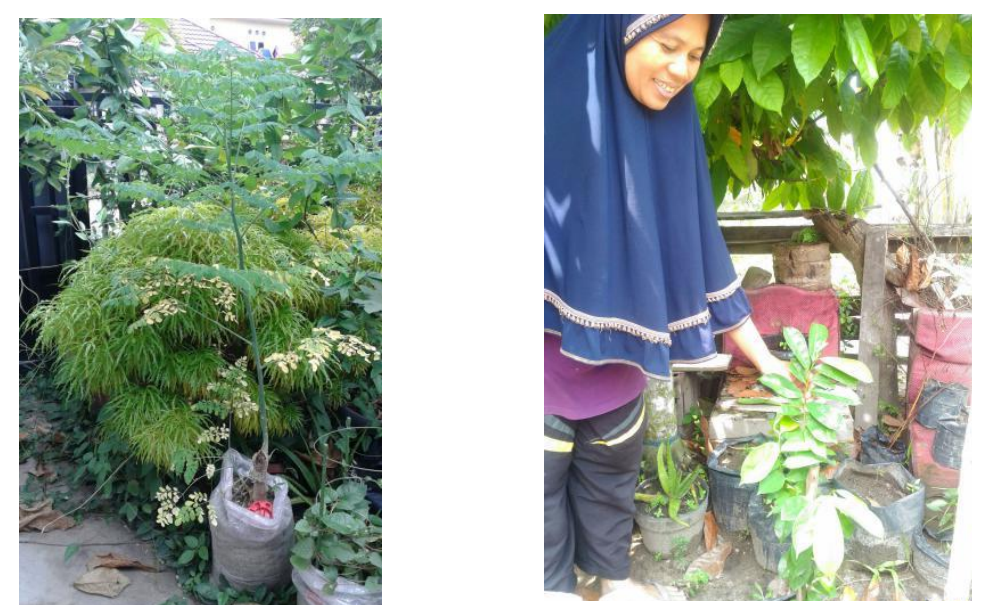

Gambar 8. Tanaman kelor dan sirsak setelah 5 bulan 


\section{KESIMPULAN}

Permasalahan yang dihadapi oleh mitra dalam pengembangan agroforestry sederhana berbasis lidah buaya adalah kurangnya pengetahuan, ketersediaan bibit, dan tehnik budidaya. Oleh karena itu Tim IbM Unilak membantu mereka dalam bentuk penyuluhan dan pelatihan, pengadaan saranaprasarana budidaya, dan pendampingan lapangan.

Hasil penyuluhan menunjukkan terdapat perbedaan pemahaman secara signifikan antara sebelum dan setelah mengikuti kegiatan sosialisasi. Sarana-prasarana agroforestry yang dibantu adalah pengadaan tanah hitam, pupuk kandang, abu sekam, dan bibit tanaman. Pendampingan lapangan dilakukan sejak mulai penyiapan media tanaman, penanaman, dan pemeliharaan.

Setelah lebih kurang lima bulan sejak penanaman tanaman lidah buaya, sirsak dan binahong tumbuh hampir $100 \%$, namun tingkat pertumbuhannya berbeda-beda. Perbedaan pertumbuhan dikarenakan perbedaan intensitas pemeliharaan, pengaruh lokasi penyimpanan, dan tempat penanaman. Sedangkan untuk jenis kelor persen tumbuhnya sekitar $45 \%$, artinya lebih banyak yang mati daripada yang hidup. Diduga bibit kelor yang dibagikan masih terlalu muda (baru berusia 2-3 minggu) sehingga masih berada pada periode kritis, dimana terjadinya perubahan lingkungan dan gangguan fisik dapat menyebabkan terjadinya kematian.

\section{DAFTAR PUSTAKA}

[1] Ashari, S., Purwantini, T.B. 2012. Porensi dan Prospek Pemanfaatan Lahan Pekarangan Untuk Mendukung Ketahanan Pangan. Jurnal Agro Ekonomi Vol 30 No 1 (2012) Hal: 13-30.

[2] Furnawanthi, I. 2002. Khasiat dan Manfaat Lidah Buaya. Jakarta: Agro Media Pustaka.

[3] Hazrat, S. , Sarvestani, Z.T., Bidgoli, A.M., Sanavy, S.A.M.M., Mohammadi, H., and Nicola, S. 2017. Effects of zeolite and water stress on growth, yield and chemicalcompositions of Aloe vera L. Agricultural Water Management 181: 66-72.

[4] Itrat, M. and Zamigar. 2013. Aloe vera: A Review Of Its Clinical Effectiveness. Int. Res. J. Pharm 4(8): 75-79

[5] Javed, S., Attaur-Rahman. 2014. Aloe Vera Gel in Food, Health Products, and Cosmetics Industry. Studies in Natural Products Chemistry 41: 261-285. https://doi.org/10.1016/B978-0444-63294-4.00009-7.

[6] Manvitha, K., and Bidya, B. 2014. Aloe vera: a wonder plant its history, cultivation and medicinal uses. Journal of Pharmacognosy and Phytochemistry 2014; 2 (5): 85-88.

[7] Nair, P.K.R. 1993. An introduction to agroforestry. Dordrecht, The Netherlands:Kluwer Academic Publishers.

[8] Nugraha, S. 2008. Analisis Kinerja Usahatani dan Pengolahan Lidah Buaya Di Kabupaten Bogor. Skripsi. Bogor: Institut Pertanian Bogor.

[9] Prastyaningsih, S.R., Ratnaningsih, A.T., Zargustin, D. 2017. IbM Kelompok Tani Lidah Buaya. Jurnal Ilmiah Pertanian Vol, 13 No. 2: 81-88.

[10] Ray, A., Ghosh, S., Ray, A., Aswatha, S.M. 2015. An analysis of the influence of growth periods on potential functionaland biochemical properties and thermal analysis of freeze-dried Aloevera L. gel. Industrial Crops and Products 76: 298-305.

[11] Reyes, T. 2008. Agroforestry systems for sustainable livelihoods and improvedland management in the East Usambara Mountains, Tanzania. Academic Dissertation. Faculty of Agriculture and Forestry of the University of Helsinki, Finland.

[12] Santosa, E. 2003. Pengaruh Jenis Pupuk Organik dan Mulsa terhadap Pertumbuhan Tanaman Lidah Buaya (Aloe vera Mill.). Bul. Agron. 31(3): 120-125.

[13] Sánchez-Machado, D.I., López-Cervantes, J., Sendón, R., Sanches-Silva, A. 2017. Aloe vera: ancient knowledge with new frontiers. Trends in Food Science \& Technology (2017), doi: 10.1016/j.tifs.2016.12.005.

[14] Sasli, I., Yahya, S., Sudradjat, Setiadi, Y., dan Sudarsono. 2008. Perbaikan Pertumbuhan dan Kualitas Tanaman Lidah Buaya di Tanah Gambut dengan Aplikasi Mikoriza Arbuskula dan Pemupukan. Bul. Agron. 36(3): 248 - 254. 
[15] Silva, H., Sagardia, S., Seguel, O., Torres, C., Tapia, C., Franck, N., and Cardemile, L. 2010. Effect of water availability on growth and water use efficiency for biomass and gel production in Aloe Vera (Aloe barbadensis M.). Industrial Crops and Products 31: 20-27.

[16] Syawal, Y. dan Wijaya, E. 2014. Pengembangan Pertanian Organik dalam Budidaya Tanaman Lidah Buaya (Aloe Vera L) dengan Memanfaatkan Abu Janjang Kelapa Sawit di Tanah Ultisol. Prosiding Seminar Nasional Lahan Sub optimal 2014, Palembang 26-27 September 2014. ISBN: 979-587-529-9 